\title{
Survey on Effect of EMF Emitted by CRT Computer Monitors in Bangladesh
}

\author{
Munima Haque*, Md. Quamruzzaman \\ Faculty of Electrical and Electronic Engineering, School of Science and Engineering, Southeast University, Bangladesh
}

Copyright (C) 2015 by authors, all rights reserved. Authors agree that this article remains permanently open access under the terms of the Creative Commons Attribution License 4.0 International License

\begin{abstract}
As the world is being industrialized and technological revolution continues, there has been an unprecedented increase in the number and diversity of electromagnetic sources. While all these devices have made our lives richer, comfortable and easier, they have been accompanied by concerned possible health risks due to their electromagnetic field (EMF) emission. Electro-Magnetic Fields commonly known as Non Ionizing Radiation is emitted from high power transmission lines, computer monitor/video display unit, radio waves of different frequencies (extremely low frequency to microwaves), telecommunication, satellite, radar etc. which causes health hazards to living system and environment. CRT monitors are still being used in various computer composing shops, photocopy machine shops. Their EMF health effects have not been studied in Bangladesh. The data were collected from various places in Dhaka, Bangladesh: Banani Super Market, Mohakhali, Farmgate Green Road, Nilkhet and Uttara. Both Electric and Magnetic fields were measured for CRT monitors. These results showed that in many cases the magnetic field radiated from the different sources are greater than the threshold limit.
\end{abstract}

Keywords EMF, NIR, WHO, ICNIRP, EMI, EMC, AML

\section{Introduction}

It is obvious that electricity is the main tool for the advancement of modern civilization. At the same time, we are also informed about the adverse effects of varying degrees of Electro-Magnetic Fields (EMF) commonly known as non-ionizing radiation (NIR) which do not ionize the media like that of ionizing radiation (i.e. $\alpha, \beta$ and $\gamma$, etc.) It is reported that high power transmission lines [1] [2], computer monitor/video display unit, radio waves of different frequencies in (extremely low frequency to microwaves) telecommunication, satellite, radar etc. also cause harm to living systems [3] [4], especially in human beings for example. It is known that high power transmission lines cause human health hazards rather than a common electrocution. Even there are evidences that the cause of clinical depression and commitment of suicide are related with the emission from the power lines [5] [6]. A significant percentage of miscarriage is recorded among women using electric blankets, electrically heated waterbeds and video display unit or computer monitor. There are instances that occupational hazards like risk of developing Acute Myeloid Leukemia (AML) may occur among the people working in the field of telecommunication. Cancerous thyroid tumor, suppression of T- lymphocyte cell etc. are also found to occur among the persons exposed to non-ionizing radiation. Nancy Wertheimer was the first scientist responsible for identifying the association between magnetic fields and childhood leukemia [7].

At the same time lower animals are reported to very much sensitive to electromagnetic fields. It is observed that animals like rats make their living brooding holes away from the high electric field and bees block-up their hives in the chronic presence of NIR/EMF. As a consequence, scientists and health physicians in developed countries have become aware of the effects of NIR [8]. Their research and observations have brought out some remarkable results linking low level alternating electromagnetic fields with serious health hazards. The $50 \mathrm{~Hz}$ and $60 \mathrm{~Hz}$ power lines fields (low frequency), pulsed radar systems and high power Extremely High Frequency (EHF) communication systems are genuine concerns for mankind.

It is suspected that the cause of Sudden Infant Death Syndrome (SIDS) may have some relation with EMF. There is also evidence that biological effect like immune deficiency, sensitive lymphocytes, disrupting DNA, cellular breakdown is being affected by NIR.

It is also known that several hundred kilometers of high power transmission lines (National Power Grid) run through the villages, fields and residential areas of Bangladesh. The length of these is extending day by day to meet the increasing power demand even in the rural areas. Besides several radio, 
television transmission and relay stations are radiating radio waves continuously. The numbers of these stations are bound to increase in the near future.

Bangladesh has many ground satellite stations and more will be installed soon for the commercial broadcasting of television programs. These will receive and transmit high frequency, high power radio waves in Giga Hertz range. Uses of PC's are increasing rapidly in offices, industries, research laboratories, banks and commercial houses even in schools, colleges and universities in our country. Use of mobile/cellular phones which uses very high frequency radio waves $(800 \mathrm{MHz}-2100 \mathrm{MHz})$ are also increasing worldwide. The total number of Mobile Phone subscriptions has reached 121.860 million at the end of January 2015 [9]. Considering these facts, it can be assumed that we are always exposed to non-ionizing radiation in our daily life mainly from artificial sources like radar, satellite, telecommunication, radio and television transmissions, microwave communications, high voltage power lines etc.

Much research has been performed in this regard. Most recently, Epidemiological survey of people working in EMF field exposed to high frequency have been investigated [10]. Also, research was performed for epidemiological survey on effect of EMF emitted by photocopy machines generally used in Dhaka city Bangladesh [11]. Survey was done on EMF emitted by Lab equipments in various labs of Southeast University in Bangladesh for possible health hazards [12]. A case study was done on EMF near high voltage transmission line [13]. Also, a review was done on Non Ionizing Radiation (NIR), its harmful effects especially from Mobile/Cell Phone and Towers [14]

Non-ionizing radiation (NIR) from a varying Electromagnetic Field (EMF) not only causes health hazards but also causes various problems or disturbances in electronic equipments. These problems or disturbance caused by EMF is called interference, commonly known as Electro-Magnetic Interference (EMI). The EMI may be defined as unintentional generation of either radiated or conducted energy that interferes with the normal operation of other electronic equipment or system. Scientists and engineers from all over the world are very much concerned about it and trying their best to overcome or at least to minimize the problem.

\section{Materials and Methods}

A magnetic Science International MF meter (Serial No 624335) was used for measuring the magnetic field values for the various CRT monitors. A Cughill Field Mouse for Biohazard Awareness was used for measuring the threshold values for both electric field and magnetic field around the machines. This Cughill Field Mouse instrument was designed by Dr. Roger Coghill of UK. The students visited physically at various locations and filled the prescribed form for the CRT monitors.

\section{Results}

\subsection{Epidemiological Survey}

Findings at different EMF sources: All the readings were taken from various parts of Dhaka, Bangladesh. In Table 1, epidemiological survey data were collected from the Banani Super Market Dhaka from 3 CRT monitor operating shops. Reading number 4 was taken from Digital Logic Design Lab (DLD lab), A.R. Tower, Southeast University, Banani, Dhaka. All these data were taken on 12.12.2013. The operators were asked questions form questionnaire forms regarding their age, working years, number of hours working per day, smoker/non-smoker, various symptoms of their health and other comments.

Table 1. Epidemiological survey of CRT Monitor Operators at Banani Super Market, Dhaka (readings 1-3). Reading number 4 was taken from Digital Logic Design Lab (DLD lab), A.R. Tower, Southeast University, Banani, Dhaka. All these data were taken on 12.12.2013.

\begin{tabular}{|c|c|c|c|c|c|c|}
\hline S.N. & $\begin{array}{c}\text { Age } \\
\text { (years) }\end{array}$ & $\begin{array}{c}\text { Working } \\
\text { years }\end{array}$ & $\begin{array}{c}\text { Working } \\
\text { Hours/day }\end{array}$ & $\begin{array}{c}\text { Smoker? } \\
\text { piece/day }\end{array}$ & Symptoms & Other observations \\
\hline 1 & 30 & 5 & 12 & $\begin{array}{c}\text { Yes } \\
(25 / \text { day })\end{array}$ & $\begin{array}{c}\text { Indigestion, insomnia, cataract, } \\
\text { stomach ache, pain in wrists \& legs, } \\
\text { skin disease \& mental depression }\end{array}$ & $\begin{array}{c}\text { Works in a congested space. He is } \\
\text { NOT aware of any health effects } \\
\text { due to EMF. }\end{array}$ \\
\hline 2 & 26 & 9 & 12 & No & No symptoms & $\begin{array}{c}\text { He is NOT aware of any health } \\
\text { effects due to EMF. }\end{array}$ \\
\hline 3 & 34 & 5 & $5-6$ & No & No symptoms & $\begin{array}{c}\text { He is NOT aware of any health } \\
\text { effects due to EMF. }\end{array}$ \\
\hline 4 & 58 & 10 & 2 & No & $\begin{array}{c}\text { Cffects due to EMF. He is fit } \\
\text { compared his age. }\end{array}$ \\
\hline
\end{tabular}


In Table 2, epidemiological survey data were collected from Uttara Dhaka from 10 CRT monitor operating shops. The operators were asked questions form questionnaire forms regarding their age, working years, number of hours working per day, smoker/non-smoker, various symptoms of their health and other comments.

Table 2. Epidemiological survey taken in Uttara. The number 1 data set were taken on 8-3-2014, from number 2-4 were taken on 9-3-2014 and numbers 5-10 were taken on 22-7-2013.

\begin{tabular}{|c|c|c|c|c|c|c|}
\hline S.N. & $\begin{array}{l}\text { Age } \\
\text { (years) }\end{array}$ & $\begin{array}{l}\text { Working } \\
\text { years }\end{array}$ & $\begin{array}{l}\text { Working } \\
\text { Hours/day }\end{array}$ & $\begin{array}{l}\text { Smoker? } \\
\text { piece/day }\end{array}$ & Symptoms & Other observations \\
\hline 1 & 20 & 2.5 & 12 & No & $\begin{array}{l}\text { Insomnia, skin disease, } \\
\text { mental depression }\end{array}$ & $\begin{array}{l}\text { He is NOT aware of any health effects due to } \\
\text { EMF. Spends huge time around monitors }\end{array}$ \\
\hline 2 & 47 & 2 & 12 & $\begin{array}{l}\text { Yes }(8-10 / \text { day }) \\
36 \text { years }\end{array}$ & $\begin{array}{l}\text { Cataract, stomach ache, pain } \\
\text { in hands, mental depression }\end{array}$ & He is aware of health effects due to EMF \\
\hline 3 & 28 & $\sim \sim 3$ & $\sim 10$ & $\begin{array}{l}\text { Yes } 10-12 / \text { day } \\
\quad \sim 6 \text { years }\end{array}$ & $\begin{array}{l}\text { Indigestion, pain in hands \& } \\
\text { legs, skin disease, mental } \\
\text { depression }\end{array}$ & $\begin{array}{l}\text { He is NOT aware of any health effects due to } \\
\text { radiation from CRT monitors }\end{array}$ \\
\hline 4 & 29 & $8-9$ & 12 & No & $\begin{array}{l}\text { Cataract, pain in hands \& } \\
\text { legs, mental depression }\end{array}$ & $\begin{array}{l}\text { He is aware of health effects due to EMF. } \\
\text { Due to long hours of work and prolonged use } \\
\text { of CRT monitor, he suffers from eye } \\
\text { problem. Also he is thin and looks ill. }\end{array}$ \\
\hline 5 & 35 & 8 & 11 & No & $\begin{array}{c}\text { Indigestion, insomnia, } \\
\text { stomach ache, pain in hands } \\
\text { \& legs, skin disease, mental } \\
\text { depression }\end{array}$ & $\begin{array}{l}\text { He is NOT aware of health effects due to } \\
\text { CRT monitors. No precautions were taken }\end{array}$ \\
\hline 6 & 24 & 5 & 12 & Yes (15/day) & $\begin{array}{l}\text { Cataract, pain in hands \& } \\
\text { legs, mental depression }\end{array}$ & $\begin{array}{l}\text { He is NOT aware of health effects due to } \\
\text { CRT monitors. No precautions were taken }\end{array}$ \\
\hline 7 & 28 & 6 & 12 & No & $\begin{array}{l}\text { Vomit, pain in hands, skin } \\
\text { disease, pain in backbone }\end{array}$ & He is aware of health effects due to EMF \\
\hline 8 & 32 & 12 & 15 & No & $\begin{array}{l}\text { Vomit, pain in hands, skin } \\
\text { disease, pain in backbone }\end{array}$ & He is aware of health effects due to EMF \\
\hline 9 & 26 & 4 & 10 & No & Vomit, mental depression & $\begin{array}{l}\text { He is NOT aware of health effects due to } \\
\text { EMF }\end{array}$ \\
\hline 10 & 29 & 8 & 7 & Yes (10/day) & $\begin{array}{l}\text { Indigestion, stomach ache, } \\
\text { pain in hands \& legs, mental } \\
\text { depression }\end{array}$ & $\begin{array}{l}\text { He is aware of health effects. He went to a } \\
\text { doctor }\end{array}$ \\
\hline
\end{tabular}


In Table 3, epidemiological survey data were collected from Nilkhet Dhaka from 17 CRT monitor operating shops. The operators were asked questions form questionnaire forms regarding their age, working years, number of hours working per day, smoker/non-smoker, various symptoms of their health and other comments.

Table 3. Epidemiological survey taken from various CRT monitor operating shops in Nilkhet, Dhaka. The first 10 data sets were taken on 11-7-2013 and serial numbers 11-17 were taken on 6-7-2013.

\begin{tabular}{|c|c|c|c|c|c|c|}
\hline S.N. & $\begin{array}{l}\text { Age } \\
\text { (years) }\end{array}$ & $\begin{array}{l}\text { Workin } \\
\text { g years }\end{array}$ & $\begin{array}{l}\text { Working } \\
\text { Hours/day }\end{array}$ & Smoker? & Symptoms & Other observations \\
\hline 1 & 31 & 2 & 8 & No & Skin disease & $\begin{array}{l}\text { He is NOT aware of health effects due to } \\
\text { EMF. No precautions were taken }\end{array}$ \\
\hline 2 & 23 & 1 & 14 & No & Stomach ache & $\begin{array}{l}\text { He is NOT aware of health effects due to } \\
\text { EMF. No precautions were taken }\end{array}$ \\
\hline 3 & 34 & 5 & 12 & No & $\begin{array}{l}\text { Indigestion, pain in hands, mental } \\
\text { depression }\end{array}$ & $\begin{array}{c}\text { He is NOT aware of health effects due to } \\
\text { EMF. }\end{array}$ \\
\hline 4 & 30 & 2 & 10 & Yes 12 years & $\begin{array}{l}\text { Indigestion, insomnia, cataract, } \\
\text { pain in legs \& hands }\end{array}$ & $\begin{array}{c}\text { He is NOT aware of health effects due to } \\
\text { EMF. }\end{array}$ \\
\hline 5 & 27 & 4 & 13 & No & $\begin{array}{l}\text { Indigestion, insomnia, cataract, } \\
\text { pain in legs \& hands, mental } \\
\text { depression }\end{array}$ & $\begin{array}{l}\text { He is NOT aware of health effects due to } \\
\text { EMF. }\end{array}$ \\
\hline 6 & 45 & 20 & 8 & No & No symptom & $\begin{array}{c}\text { He is NOT aware of health effects due to } \\
\text { EMF. }\end{array}$ \\
\hline 7 & 24 & 7 & 8 & No & No symptom & $\begin{array}{l}\text { He is NOT aware of health effects due to } \\
\text { EMF. }\end{array}$ \\
\hline 8 & 38 & 10 & $8-9$ & Yes 20 years & Pain in legs, mental depression & $\begin{array}{l}\text { He is NOT aware of health effects due to } \\
\text { EMF. }\end{array}$ \\
\hline 9 & 42 & 12 & 10 & $\begin{array}{c}\text { Yes } \\
\sim 20 \text { years }\end{array}$ & Insomnia, eye problem & $\begin{array}{l}\text { He is NOT aware of health effects due to } \\
\text { EMF. }\end{array}$ \\
\hline 10 & 34 & 8 & 10 & No & $\begin{array}{l}\text { Insomnia, skin disease, mental } \\
\text { depression }\end{array}$ & $\begin{array}{c}\text { He is NOT aware of health effects due to } \\
\text { EMF. }\end{array}$ \\
\hline 11 & 37 & $7-8$ & $\sim 9$ & $\begin{array}{c}\text { Yes } \\
\text { 1pack/day }\end{array}$ & $\begin{array}{l}\text { Vomit, insomnia, pain in legs \& } \\
\text { hands }\end{array}$ & $\begin{array}{c}\text { He is NOT aware of health effects due to } \\
\text { EMF. }\end{array}$ \\
\hline 12 & 20 & 2 & & No & $\begin{array}{l}\text { Vomit, indigestion, cataract, } \\
\text { stomach ache, pain in legs \& } \\
\text { hands, mental depression }\end{array}$ & $\begin{array}{l}\text { He is NOT aware of health effects due to } \\
\text { EMF. }\end{array}$ \\
\hline 13 & 29 & $>12$ & $>12$ & $\begin{array}{l}\text { Yes } \\
7 / \text { day }\end{array}$ & $\begin{array}{l}\text { Indigestion, pain in hands, skin } \\
\text { disease, mental depression }\end{array}$ & $\begin{array}{l}\text { He is NOT aware of health effects due to } \\
\text { EMF. The operator looked very weak, } \\
\text { but he did not take any doctor advice. }\end{array}$ \\
\hline 14 & 38 & 4 & 8 & Yes 1 year & $\begin{array}{l}\text { Indigestion, insomnia, pain in legs } \\
\quad \& \text { hands, skin disease }\end{array}$ & $\begin{array}{l}\text { He is NOT aware of health effects due to } \\
\text { EMF. }\end{array}$ \\
\hline 15 & 40 & 12 & 8 & No & $\begin{array}{l}\text { Indigestion, insomnia, pain in legs } \\
\qquad \text { hands }\end{array}$ & $\begin{array}{l}\text { He is NOT aware of health effects due to } \\
\text { EMF. }\end{array}$ \\
\hline 16 & 36 & 7 & 8 & No & Insomnia, stomach ache & $\begin{array}{c}\text { He is NOT aware of health effects due to } \\
\text { EMF. }\end{array}$ \\
\hline 17 & 35 & 15 & 7 & Yes ( $>8 /$ day) & Pain in hands & $\begin{array}{l}\text { He is NOT aware of health effects due to } \\
\text { EMF. The operator did not look well, but } \\
\text { he did not see a doctor. }\end{array}$ \\
\hline
\end{tabular}




\subsection{EMF Measurements}

In Table 4, EMF readings 1-3 were taken from Banani Super Market. The readings of 4.1-4.8 were taken from DLD (Digital Logic Design) labs, A.R. Tower, Southeast University, Banani, Dhaka. These data were taken on 12.12.2013. A table was completed with the following information: PC company name, model number and the following data were taken using the Coghill mouse: Threshold distance in front of the screen measured from the centre of the screen $\mathrm{cm}$, threshold distance at $45^{\circ}$ angle from the normal drawing at the centre in $\mathrm{cm}$, threshold distance at the top of the monitor in $\mathrm{cm}$. The maximum magnetic field was measured using the MF meter. Observations if any were also noted.

Table 4. EMF readings 1-3 taken from Banani Super Market. The readings of 4.1-4.8 were taken from DLD (Digital Logic Design) labs, A.R. Tower, Southeast University, Banani, Dhaka. These data were taken on 12.12.2013.

\begin{tabular}{|c|c|c|c|c|c|c|c|c|c|c|}
\hline \multirow[t]{2}{*}{ S.N. } & \multirow[t]{2}{*}{$\begin{array}{l}\text { PC monitor } \\
\text { company }\end{array}$} & \multirow[t]{2}{*}{ Model No } & \multicolumn{2}{|c|}{$\begin{array}{l}\text { Threshold dis. In } \\
\text { front of the screen } \\
\text { measured from the } \\
\text { centre of the } \\
\text { screen } \mathrm{cm}\end{array}$} & \multicolumn{2}{|c|}{$\begin{array}{l}\text { Threshold dis. } \\
\text { At } 45^{\circ} \text { angle } \\
\text { from the normal } \\
\text { drawing at the } \\
\text { centre cm }\end{array}$} & \multicolumn{2}{|c|}{$\begin{array}{c}\text { Threshold } \\
\text { distance at the top } \\
\text { of the monitor } \mathrm{cm}\end{array}$} & \multirow[t]{2}{*}{$\begin{array}{l}\text { MF in mG } \\
\text { (max.) }\end{array}$} & \multirow[t]{2}{*}{ Observations } \\
\hline & & & $\mathrm{EF}$ & MF & $\mathrm{EF}$ & MF & $\mathrm{EF}$ & MF & & \\
\hline 1 & Monarch & 1731 PAP China & 122 & 15 & 91.5 & 122 & 61 & Inf. & 15.5 & $\begin{array}{l}\text { Too congested } \\
\text { space }\end{array}$ \\
\hline 2 & Samsung & $\begin{array}{c}\text { Syncmaster 591s } \\
\text { Malaysia } 2004\end{array}$ & 106.7 & 15 & 76 & 10 & 91.5 & 7.5 & 20.6 & - \\
\hline 3 & Samsung & $\begin{array}{c}\text { 550s Malaysia } \\
2001\end{array}$ & 96.5 & 15 & - & 45.7 & 0 & 45.7 & - & $\begin{array}{l}\text { Too many power } \\
\text { lines, lights, } \\
\text { LCDs, and } \\
\text { refrigerators }\end{array}$ \\
\hline 4.1 & $\begin{array}{c}\text { Samsung } \\
\text { SEUPC } 136\end{array}$ & $\begin{array}{c}\text { Syncmaster } 551 \\
\text { Malaysia } \\
\text { Aug2002 }\end{array}$ & 61 & 7.6 & 48 & 33 & 39 & 43 & 12.6 & - \\
\hline 4.2 & SEUPC 26 & Apr 2003 & 104.1 & 0 & 50.8 & 0 & 55.9 & 0 & - & - \\
\hline 4.3 & SEUPC 80 & Apr 2003 & 30.5 & 0 & 19 & 0 & 16.5 & 11.4 & - & - \\
\hline 4.4 & SEUPC 130 & Aug 2002 & 50.8 & 0 & 28 & 0 & 19 & 0 & - & - \\
\hline 4.5 & $\begin{array}{c}\text { SEUPC } \\
1-2-22-1-1-1 \\
3 / \mathrm{A} 02 \\
\end{array}$ & Aug 2002 & 61 & 0 & 50.8 & 0 & 33 & 8.9 & - & - \\
\hline 4.6 & SEUPC 96 & Aug 2002 & 41.9 & 0 & 43 & 0 & 52 & 5 & - & - \\
\hline 4.7 & $\begin{array}{c}\text { LG } \\
\text { SEUPC } 92\end{array}$ & - & 66 & 0 & 35.5 & 0 & 28 & 17.8 & - & - \\
\hline 4.8 & SEUPC 86 & Aug 2001 & 76 & 0 & 48 & 0 & 50.8 & 20.3 & - & - \\
\hline
\end{tabular}


Table 5. EMF reading taken at Uttara. Reading 1 was taken on 8-3-2014, 2-4 readings were taken on 9-3-2014 and readings from 5 to 10 were taken on date 22-7-2013. These readings were all taken from typing/editing shops at Uttara shopping area.

\begin{tabular}{|c|c|c|c|c|c|c|c|c|c|c|}
\hline \multirow[t]{2}{*}{ S.N. } & \multirow[t]{2}{*}{$\begin{array}{l}\text { P C monitor } \\
\text { company }\end{array}$} & \multirow[t]{2}{*}{ Model No } & \multicolumn{2}{|c|}{$\begin{array}{l}\text { Threshold dis. In } \\
\text { front of the } \\
\text { screen measured } \\
\text { from the centre } \\
\text { of the screen } \mathrm{cm}\end{array}$} & \multicolumn{2}{|c|}{$\begin{array}{l}\text { Threshold dis. } \\
\text { At } 45^{\circ} \text { angle } \\
\text { from the } \\
\text { normal } \\
\text { drawing at the } \\
\text { centre } \mathrm{cm}\end{array}$} & \multicolumn{2}{|c|}{$\begin{array}{l}\text { Threshold } \\
\text { distance at the } \\
\text { top of the } \\
\text { monitor } \mathrm{cm}\end{array}$} & \multirow[t]{2}{*}{$\begin{array}{l}\text { MF in } \\
\text { mG } \\
\text { (max.) }\end{array}$} & \multirow[t]{2}{*}{ Observations } \\
\hline & & & EF & MF & EF & MF & $\mathrm{EF}$ & MF & & \\
\hline 1 & Samsung & $\begin{array}{l}\text { Syncmaster } \\
\text { 793DF } \\
\text { South Korea }\end{array}$ & 86 & 52 & 105 & 63 & 50 & 31 & $\begin{array}{c}154.6 \\
\mathrm{mG}\end{array}$ & - \\
\hline 2 & Samsung & $\begin{array}{l}\text { Syncmaster } 55 / \mathrm{S}, \\
\text { Korea } 2002\end{array}$ & 72 & 42 & 42 & 24 & 105 & 72 & 167 & $\begin{array}{l}\text { There were a lot of electric } \\
\text { instrument in the shop. The } \\
\text { shop was very small and } \\
\text { narrow. The operator's } \\
\text { sitting place was alarming }\end{array}$ \\
\hline 3 & Dell & $\begin{array}{l}\text { E } 771 \text { C Japan } \\
2007\end{array}$ & 82 & 53 & 28 & 18 & 102 & 70 & 169.5 & $\begin{array}{l}\text { The shop is very small. } \\
\text { There are two photocopy } \\
\text { machines and one computer. } \\
\text { Two operators work there. }\end{array}$ \\
\hline 4 & Samsung & $\begin{array}{l}\text { Syncmaster 591S } \\
\text { Korea } 2008\end{array}$ & 76 & 46 & 87 & 49 & 105 & 75 & 184.5 & $\begin{array}{l}\text { The place is dingy, with all } \\
\text { the electrical devices placed } \\
\text { in one side, near the } \\
\text { switchboard. }\end{array}$ \\
\hline 5 & Samsung & SM 794MG 2005 & - & 88 & - & - & - & - & 15 & $\begin{array}{l}\text { As there are so many } \\
\text { electronic elements working } \\
\text { surrounding the } \\
\text { experimental monitor, they } \\
\text { were not able to measure any } \\
\text { electric field threshold } \\
\text { distances. }\end{array}$ \\
\hline 6 & Samsung & $\begin{array}{l}\text { Syncmaster 550s } \\
\quad \text { China } 2005\end{array}$ & - & 120 & - & - & - & - & 18 & $\begin{array}{l}\text { Could not get any EF } \\
\text { Threshold Distance (EF-TD) } \\
\text { due to many electric } \\
\text { elements around. }\end{array}$ \\
\hline 7 & Samsung & 591s Korea 2004 & - & 75 & - & - & - & - & 12 & $\begin{array}{l}\text { There were many electric } \\
\text { instruments in shop, so } \\
\text { EF-TD could not be } \\
\text { measured }\end{array}$ \\
\hline 8 & Samsung & 42312004 & - & 75 & - & - & - & - & 12 & $\begin{array}{l}\text { Many electric instruments in } \\
\text { shop, so EF-TD could not be } \\
\text { measured }\end{array}$ \\
\hline 9 & Samsung & Japan 2003 & - & 60 & - & - & - & - & 10 & $\begin{array}{l}\text { EF-TD could not be } \\
\text { measured due to many } \\
\text { electric instruments in shop }\end{array}$ \\
\hline 10 & Samsung & China 2007 & - & 50 & - & - & - & - & 12 & $\begin{array}{c}\text { EF \& MF TDs could not be } \\
\text { measured }\end{array}$ \\
\hline
\end{tabular}

In Table 5, EMF readings were taken from Uttara. Of the 10 readings, serial number 1 was taken on 8-3-2014, reading numbers 2-4 were taken on 9-3-2014, and readings 5-10 were taken on 22-7-2013. Similar to table 4, all the same parameters were noted and measured for EMF reading.

In Table 6, EMF readings were taken from Nilkhet editing/typing shops. Of the 17 readings, serial numbers $1-10$ were taken on 11-7-2013, and reading numbers 11-17 were taken on 6-7-2013. Similar to table 4 and 5, all the same parameters were noted and measured for EMF reading. 
Table 6. EMF reading taken at Nilkhet. Readings 1-10 were taken on 11-7-2013 and readings 11-17 were taken on 6-7-2013.

\begin{tabular}{|c|c|c|c|c|c|c|c|c|c|c|}
\hline \multirow[t]{2}{*}{ S.N } & \multirow[t]{2}{*}{$\begin{array}{l}\text { PC monitor } \\
\text { company }\end{array}$} & \multirow[t]{2}{*}{ Model No } & \multicolumn{2}{|c|}{$\begin{array}{l}\text { Threshold dis. } \\
\text { In front of the } \\
\text { screen } \\
\text { measured from } \\
\text { the centre of } \\
\text { the screen } \mathrm{cm}\end{array}$} & \multicolumn{2}{|c|}{$\begin{array}{l}\text { Threshold dis. } \\
\text { At } 45^{\circ} \text { angle } \\
\text { from the } \\
\text { normal } \\
\text { drawing at the } \\
\text { centre } \mathrm{cm}\end{array}$} & \multicolumn{2}{|c|}{$\begin{array}{l}\text { Threshold } \\
\text { distance at the } \\
\text { top of the } \\
\text { monitor cm }\end{array}$} & \multirow[t]{2}{*}{$\begin{array}{l}\text { MF in } \\
\text { mG } \\
\max .\end{array}$} & \multirow[t]{2}{*}{ Observations } \\
\hline & & & EF & MF & EF & MF & $\mathrm{EF}$ & MF & & \\
\hline 1 & Samsung & $\begin{array}{c}\text { Syncmaster 793DF } \\
\text { Korea } 2006\end{array}$ & 63 & 34 & 60 & 30 & 71 & 28 & 122 & - \\
\hline 2 & Samsung & $\begin{array}{c}\text { Syncmaster } 793 \text { ng } \\
\text { Korea } 2002\end{array}$ & 46 & 37 & 52 & 32 & 42 & 28 & 144 & - \\
\hline 3 & Samsung & 59152007 & 35 & 48 & 45 & 30 & 28 & 12 & 154 & - \\
\hline 4 & Samsung & 793DF 2002 & 65 & 33 & 67 & 30 & 57 & 27 & 124 & - \\
\hline 5 & Samsung & $\begin{array}{l}\text { Syncmaster 591s } \\
\text { Korea } 2005\end{array}$ & 90 & 30 & 81 & 47 & 80 & 57 & 164 & - \\
\hline 6 & Samsung & $\begin{array}{c}\text { Syncmaster 551 N } \\
\text { Korea } 1995\end{array}$ & 45 & 56 & 48 & 49 & 37 & 31 & 134 & - \\
\hline 7 & Samsung & $\begin{array}{c}\text { Syncmaster 591s } \\
\text { Korea } 2006\end{array}$ & 55 & 28 & 51 & 32 & 42 & 31 & 144 & - \\
\hline 8 & Samsung & 551s Korea 1994 & 53 & 15 & 46 & 27 & 41 & 17 & 118 & - \\
\hline 9 & IBM & $\begin{array}{c}\text { Think vision USA } \\
2006\end{array}$ & 38 & 22 & 36 & 23 & 31 & 20 & 112 & - \\
\hline 10 & Philips & $\begin{array}{l}\text { 105E Singapore } \\
2005\end{array}$ & 65 & 27 & 62 & 24 & 72 & 34 & 138 & 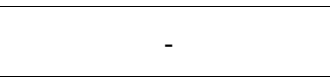 \\
\hline 11 & LG & - & 61 & - & 53 & - & 58 & - & - & $\begin{array}{l}\text { So many electronic machine } \\
\text { in shop, could not measure } \\
\text { MF-TD values }\end{array}$ \\
\hline 12 & Philips & - & 53 & - & 48 & - & 61 & - & 73 & $\begin{array}{l}\text { MF-TD could not be } \\
\text { measured, too many } \\
\text { electrical machines in shop }\end{array}$ \\
\hline 13 & Samsung & $\begin{array}{l}\text { Syncmaster } 591 \mathrm{~s} \\
\text { N.Korea }\end{array}$ & 61 & - & 46 & - & 58 & - & 76 & $\begin{array}{l}\text { There were many electrical } \\
\text { machines in the shop at a } \\
\text { small distance, so did not get } \\
\text { MF-TD values }\end{array}$ \\
\hline 14 & LG & E-105 & 61 & - & 48 & - & 58 & - & 86 & $\begin{array}{l}\text { MF-TD could not be } \\
\text { measured, more than one } \\
\text { electrical machines in shop }\end{array}$ \\
\hline 15 & LG & E-105 & 61 & - & 48 & - & 58 & - & 86 & $\begin{array}{l}\text { There were many electrical } \\
\text { machines in the shop at a } \\
\text { small distance, so did not get } \\
\text { MF-TD values }\end{array}$ \\
\hline 16 & LG & Q-07 & 63.5 & - & 48 & - & 58 & - & 68 & $\begin{array}{l}\text { There were many electrical } \\
\text { machines in the shop at a } \\
\text { small distance, so did not get } \\
\text { MF-TD }\end{array}$ \\
\hline 17 & Samsung & Syncmaster $749 \mathrm{Mg}$ & 58 & - & 51 & - & 56 & - & 29 & $\begin{array}{l}\text { So many electronic machine } \\
\text { in shop, could not measure } \\
\text { MF-TD values }\end{array}$ \\
\hline
\end{tabular}

Data also has been taken and are given in tables 7-10 from as early as year 2002, of Magnetic Field and Electric Field threshold distances and magnetic field values from various PC Monitors at different labs of Institute of Electronics (IE), Atomic Energy Commission (AEC), Savar, Dhaka (data taken on 7.11.2002). In table 7, Threshold Distance of both electric and magnetic fields from various PC Monitors are given. These readings were taken in front of the screen of the monitor, $45^{\circ}$ angles from the screen and also on top of the monitor. In table 8, variation of Magnetic Field (MF) of a KOBIAN monitor was observed. The readings were taken after installation with just powered on, after 5 days, after 10 days, after 4 months and 6 months. The magnetic fields were measured from front, back and at $45^{\circ}$ angles. In table 9, Magnetic Field (MF) radiated from FLATRON PC Monitor were measured at various times starting from year 2002 till 2004. PC monitor FLATRON E 700S (LG Pentium-3) Model No. EB 770G-NA was used for these measurements. Magnetic field values at front, back and at $45^{\circ}$ angles (both left and right) were measured. In table 10, magnetic Field and Electric Field threshold distances from various PC Monitors at different labs of Institute of Electronics (IE), Atomic Energy Commission (AEC), Savar, Dhaka (data taken on 7.11.2002). Three FLATRON E 700S (LG Pentium-3) Model No. EB 770G-NA monitors were used and three LG studioworks $563 \mathrm{~N}$ monitors were used in this study. Threshold distances from front, back and at $45^{\circ}$ angles were measured for these cases. 
Table 7. Threshold Distance from various PC Monitors

\begin{tabular}{|c|c|c|c|c|c|c|c|}
\hline \multirow{2}{*}{ PC Monitor } & \multirow{2}{*}{ Model No } & \multicolumn{2}{|c|}{$\begin{array}{c}\text { Threshold dis. in front of the } \\
\text { screen measured from the } \\
\text { center of the screen }(\mathrm{cm})\end{array}$} & $\begin{array}{c}\text { Threshold distance at } 45^{0} \text { angle } \\
\text { from the normal drawn at the } \\
\text { center }(\mathrm{cm})\end{array}$ & $\begin{array}{c}\text { Threshold distance at } \\
\text { the top of the monitor } \\
\text { (cm) }\end{array}$ \\
\cline { 3 - 9 } & & EF & MF & EF & MF & EF & MF \\
\hline DEC & PC-320 SXLp & 30 & 9.5 & 81 & 27 & 26 & 7 \\
\hline SONIX & P4 compro & 33 & 11.5 & 85 & 36 & 18 & 8 \\
\hline IBM & Model 30 & 15 & 6 & 48 & 19.5 & 30 & 5 \\
\hline PHILIPS & PRO 7BM 749 & 8 & 1.3 & 15 & 143 & 31.5 & 40 \\
\hline COMPAQ & Protineu 4133 & 12.5 & 22 & 37 & 75 & 12.5 & 27 \\
\hline MICROWAY & TE5154 & 7.5 & 15 & 21 & 33 & 18 & 17 \\
\hline DELL & $325 P$ & 5 & 12 & 13 & 50 & 4 & 13 \\
\hline COMPAQ & Data mini 286 Compact & 27.5 & 12 & 72 & 29 & 30 & 23 \\
\hline
\end{tabular}

Table 8. Variation of Magnetic Field (MF) of KOBIAN Monitor under observation

\begin{tabular}{|c|c|c|c|}
\hline \multirow{2}{*}{ Period of installation } & \multicolumn{2}{|c|}{ Magnetic Field (mG) } & At 450 \\
\cline { 2 - 4 } & Front & Back & 0.4 \\
\hline Just powered on & 0.7 & 0.8 & 1.2 \\
\hline After 5 days & 1.3 & 2.6 & 5.8 \\
\hline After 10 days & 23 & 143.4 & 8.7 \\
\hline After 4 months & 23.2 & 149.3 & 8.8 \\
\hline After 6 months & 24.5 & 149.7 & \\
\hline
\end{tabular}

Table 9. Magnetic Field (MF) radiated from FLATRON PC Monitor

\begin{tabular}{|c|c|c|c|c|c|}
\hline \multirow{2}{*}{$\begin{array}{c}\text { S1. } \\
\text { N1.. }\end{array}$} & Instrument Specification Type/ Model and date of investigation & \multirow{2}{*}{ Front (mG) } & \multicolumn{2}{|c|}{$\begin{array}{c}\text { Back } \\
(\mathrm{mG})\end{array}$} & \multicolumn{2}{|c|}{ At $45^{\circ} \mathrm{mG}$} \\
\cline { 3 - 7 } & Left & Right \\
\hline 1 & FLATRON E 700S (LG Pentium-3) Model No. EB 770G-NA 21/11/2002 & 11 & 70 & 5 & 7 \\
\hline 2 & FLATRON E 700S (LG Pentium-3) Model No. EB 770G-NA 25/5/2003 & 12 & 75 & 6 & 8 \\
\hline 3 & FLATRON E 700S (LG Pentium-3) Model No. EB 770G-NA 4/12/2003 & 13 & 78 & 6.5 & 8.2 \\
\hline 4 & FLATRON E 700S (LG Pentium-3) Model No. EB 770G-NA 6/6/2004 & 14 & 80 & 6.5 & 8.3 \\
\hline 5 & FLATRON E 700S (LG Pentium-3) Model No. EB 770G-NA 22/11/2004 & 14.1 & 75 & 6 & 8.1 \\
\hline 6 & FLATRON E 700S (LG Pentium-3) Model No. EB 770G-NA 21/11/2002 & 10.5 & 71 & 4.5 & 5.5 \\
\hline 7 & FLATRON E 700S (LG Pentium-3) Model No. EB 770G-NA25/5/2003 & 11 & 75 & 5 & 6 \\
\hline 8 & FLATRON E 700S (LG Pentium-3) Model No. EB 770G-NA 4/12/2003 & 12 & 78 & 5.2 & 6.3 \\
\hline 8 & FLATRON E 700S (LG Pentium-3) Model No. EB 770G-NA 6/6/2004 & 13 & 79 & 5.4 & 6.3 \\
\hline 10 & FLATRON E 700S (LG Pentium-3) Model No. EB 770G-NA 22/11/2004 & 14.3 & 81 & 7.6 & 7.7 \\
\hline
\end{tabular}

Table 10. Magnetic Field and Electric Field threshold distances from various PC Monitors at different labs of Institute of Electronics (IE), Atomic Energy Commission (AEC), Savar, Dhaka (data taken on 7.11.2002)

\begin{tabular}{|c|c|c|c|c|c|c|c|}
\hline \multirow{2}{*}{$\begin{array}{c}\text { S1. } \\
\text { N1o. }\end{array}$} & $\begin{array}{c}\text { Instrument Specification Type/ Model and date of } \\
\text { investigation }\end{array}$ & \multicolumn{2}{|c|}{$\begin{array}{c}\text { Threshold distance } \\
\text { Front }(\mathrm{cm})\end{array}$} & \multicolumn{2}{|c|}{$\begin{array}{c}\text { Threshold } \\
\text { distance Back } \\
(\mathrm{cm})\end{array}$} & $\begin{array}{c}\text { Threshold distance at } 45^{\circ} \\
\text { angle from the normal } \\
\text { drawn at the center (cm) }\end{array}$ \\
\cline { 3 - 9 } & & EF & MF & EF & MF & EF & MF \\
\hline 1 & FLATRON E 700S (LG Pentium-3) Model No. EB 770G-NA & Nil & 18 & 15 & 50 & 11 & 20 \\
\hline 2 & FLATRON E 700S (LG Pentium-3) Model No. EB 770G-NA & Nil & 17 & 14 & 48 & 12 & 20 \\
\hline 3 & FLATRON E 700S (LG Pentium-3) Model No. EB 770G-NA & Nil & 25 & 15 & 46 & 11.5 & 18 \\
\hline 4 & LG studioworks 563 N & Nil & 15 & 18 & 40 & 8 & 25 \\
\hline 5 & LG studioworks 563 N & Nil & 18 & 18 & 55 & 7.5 & 28 \\
\hline 6 & LG studioworks 563 N & Nil & 16 & 17.5 & 53 & 7 & 26 \\
\hline
\end{tabular}




\section{Discussions}

From epidemiological studies given in tables 1-3 it has been found that common diseases from among the workers are indigestion, vomit, insomnia, pain in hands and legs, stomach ache, mental depression, skin disease, cataract, sexual problems, hairs turning white etc. In many of the photocopier shops the operators were working in congested space with lots of machineries around. There are many devices and power lines around them, having a congested environment and low circulation of air. Most of these CRT monitor operators are not aware of any adverse health effects due to its use. Some of the operators are smokers and have been for a couple of years, which might have had some negative effects on their health.

From the EMF measurement studies given in tables 4-6, it was found from the results that the magnetic field values are much higher than the threshold level. Because of the nature of the wiring both in the ceiling and floor, all the rooms had higher magnetic field than threshold value. There were many electrical machines in the shop at a small distance, so did not get magnetic field threshold values. Most of the places under study were dingy, and in most cases lots of electrical devices placed in the shops, some near the switchboards. Operators work on an average of 10-13 hours a day in those shops. We have in mind to include other regions for the study to continue. In rural areas in Bangladesh, these CRT monitor shops still prevails due to less expensive purchase of CRT PC monitors.

EMF measurement studies given in tables 7-10, these monitors were taken from as early as year 2002. In table 7, some of the threshold distances are must higher. In table 8 , it is seen that only within 10 days time, the KOBIAN monitor has a higher magnetic field reading increasing to $143.4 \mathrm{mG}$ with starting at only $0.8 \mathrm{mG}$ when powered on. In tables 9 and 10, the FLATRON PC monitors and LG Studioworks monitors show higher magnetic field values at the back of the instrument. These data indicates that at that period, the CRT monitors were extensively used but most of the models have now become obsolete or not being used anymore.

A potential hazard to health can be produced either as a result of the exposure of the human body to NIR, or by interaction with technical devices, which are themselves affected by NIR and they give rise to health hazards (e.g. interference with electro medical devices, unintentional triggering of electrically activated detonator and ignition of flammable materials). This is especially true if the individuals concerned are not aware of the potential hazard to be unable to identify it.

\section{Conclusions}

From the above lab results, it has been found that in most cases the magnetic field has crossed threshold value. The electric field also has a higher threshold value in some of the equipemnts. Also, the magnetic field maximum exposure was nearly $200 \mathrm{mG}$ in many cases. Wiring must be done according to the building code 2012.It is hoped that this survey will be helpful as a preventive measure for photocopier operators who might get affected tomorrow. Same kind of experimental data on epidemiological survey can be done in other parts of Bangladesh. There are couple of factors for occurrence of these illnesses, amongst them excessive smoking, exposure to radioactive elements, fire hazards etc. NIR may be one of the factors for causing or enhancing these illnesses. It might have direct or indirect effect for affecting the overall health issues. Although it cannot be said that NIR is the direct cause for the illnesses, rigorous studies needs to be carried out in order to arrive at this conclusion. For this further works in broad area and time periods are required.

In order to get rid of the health hazards caused by all those systems, people should be aware of them and accordingly precautionary measures should be taken. It is necessary to be acquainted with the harmful effects of non-ionizing radiations on living systems and also on the environment that we are living in and to find appropriate corrective measures for minimizing or controlling the hazards of NIR as far as practicable. Also, the power consumption of a CRT monitor is more than 10 times than a LED or LCD monitor. The general public should be educated regarding the harmful effects of CRT monitors and replace them by LED/LCD ones, which are becoming much cheaper nowadays even in Bangladesh within the financial capabilities of general public. That's why many typing/editing shops in Dhaka city which are now well off have replaced their CRT monitors with LED/LCD monitors. It is to be noted that LED/LCD monitors also take less space in the shop, which is a win- win situation.

Since magnetic field is more harmful than electric field, there must be a limit both in the residential and occupational levels between 0.2 to $0.3 \mu \mathrm{T}$ or $2.5 \mathrm{mG}$. (This value is internationally recognized as standard limit in many countries). However, for the staff working at very high frequency transmitting stations, safe precautions such as wearing of special clothing, screened helmets and secured goggles should be taken. The duration of exposure must be kept to the minimum possible. It must be ensured that intensity of radiation in the body does not exceed the recommended maximum level $\left(10 \mathrm{~mW} / \mathrm{cm}^{2}, 195 \mathrm{~V} / \mathrm{m}\right.$ in U.S.A. and $0.1 \mathrm{~mW} / \mathrm{cm}^{2}, 20 \mathrm{~V} / \mathrm{m}$ in CIS).

\section{REFERENCES}

[1] M. Coleman; V. Bera. A Review of Epidemiological Studies of the Health Effects of Living Near or Working with Electricity Generation and Transmission Equipment. International Journal of Epidemiology. Volume 17, Issue 1, pp. 1-13, 1988

[2] G. Draper; T. Vincent; M.E. Kroll; J. Swanson. Childhood cancer in relation to distance from high voltage power lines in 
England and Wales: a case-control study. BMJ. 330 (7503): 1290,2005

[3] J.M. Al-Bareeq. Health Risks of Electromagnetic Field. Editorial. Bahrain Medical Bulletin. Volume 20, Issue 1, 1998

[4] Z. Ziang. Considering factors in Chinese EMF standard. 3rd International EMF Seminar in China: Electromagnetic Fields and Biological Effects. Guilin, China: October 13-17, 2003. [Retrieved on 05.08.2012]

[http://www.who.int/peh-emf/meetings/archive/en/proceedin gs_eng.pdf\#page=89] 2003

[5] E. van Wijngaarden; D. A. Savitz; R.C. Kleckner; J. Cai; D. Loomis. Exposure to electromagnetic fields and suicide among electric utility workers a nested case-control study. West J Med. Volume 173, Issue 2, pp. 94-100, 2000

[6] K. J. Fernie; S. J. Reynolds. The Effects of Electromagnetic Fields from Power Lines on Avian Reproductive Biology and Physiology: a Review. Journal of Toxicology and Environmental Health, Part B, 8: pp. 127-140, 2005

[7] N Wertheimer, ED Leeper. Electrical wiring configurations and childhood cancer. American journal of epidemiology. Oxford Univ Press, 1979

[8] M. H. Repacholi. An Overview of WHO's EMF Project and the Health Effects of EMF Exposure. Proceedings of the International Conference on Non-Ionizing Radiation at UNITEN (ICNIR 2003), Electromagnetic Fields and Our Health, 20th-22nd October, 2003
[9] Mobile Phone Subscribers in Bangladesh. Bangladesh Telecommunication Regulatory Commission. [Retrieved on 28.08.2015] Source

http://www.btrc.gov.bd/content/mobile-phone-subscribers-ba ngladesh-january-2015

[10] M. Quamruzzaman, M. Haque. 2012: Epidemiological Survey of People Working in EMF Field Exposed to High Frequency. Proceedings of the Global Engineering, Science and Technology Conference 2012, 28-29 December, Dhaka, Bangladesh

[11] M. Haque, M. Quamruzzaman, 2015: Epidemiological survey on effect of EMF emitted by photocopy machines generally used in Dhaka city Bangladesh. IJRET: International Journal of Research in Engineering and Technology. Volume 4, Issue 4, pp 92-100, April 2015

[12] M. Quamruzzaman, M.Haque, 2015: Survey of EMF emitted by Lab equipments in various labs of Southeast University in Bangladesh for possible preventive health hazards. IFRSA International Journal Of Electronics Circuits And Systems. Volume 4, issue 1, pp 26-32, Jan 2015

[13] M. Quamruzzaman, Munima Haque, Farruk Ahmed, Md. Shahab Zaman, 2014: Effects of electromagnetic fields (EMF) near high voltage transmission line: a case study. Bangladesh Journal of Medical Physics Volume 7, Issue 1, pp. 66-68, 2014

[14] M. Quamruzzaman, M. Haque, 2014: Non Ionizing Radiation (NIR), its harmful effects especially from Mobile/Cell Phone and Towers. Southeast University Journal of Science and Engineering, Volume 8, Issue 1, 2014 